\title{
PENGEMBANGAN LKS DAN PENERAPANNYA UNTUK MENINGKATKAN HASIL BELAJAR MATERI POKOK STOIKIOMETRI SISWA KELAS X SMAN 1 BATULAYAR TAHUN PELAJARAN 2015/2016
}

\author{
Sumiati \\ SMAN 1 Batulayar, Lombok Barat, Nusa Tenggara Barat, Indonesia \\ Email : sumiati_guru@yahoo.com
}

\begin{abstract}
Abstrak: Penelitian ini bertujuan untuk mengetahui apakah pengembangan LKS dan penerapannya dapat meningkatkan hasil belajar siswa pokok bahasan stoikiometri siswa kelas X SMAN 1 Batulayar 2015/2016. Metode penelitian yang digunakan adalah penelitian tindakan kelas (PTK) yang secara umum terdiri dari 2 (dua) siklus. Masing-masing siklus terdapat 4 (empat) tahapan yaitu perencanaan, tindakan, observasi, dan refleksi. Penelitian ini dilaksanakan di kelas X SMAN 1 Batulayar dengan jumlah siswa 29 orang. Penelitian ini difokuskan pada materi hukum-hukum dasar kimia, konsep mol yang mencakup konversi jumlah mol ke dalam jumlah partikel, jumlah massa, dan jumlah volume. Teknik pengumpulan data yang digunakan adalah tes, lembar observasi dan angket. Dari hasil penelitian pada siklus II terjadi peningkatan aktivitas dan hasil belajar siswa dari siklus I yaitu, pada siklus II diperoleh rata-rata nilai pos test siswa 77 dan prosentase ketuntasan hasil belajar mencapai 78,57\% (siswa mencapai nilai $\geq 70$ ). Sementara pada siklus I rata-rata nilai siswa hanya 58 dan prosentase ketuntasan hasil belajar hanya mencapai 54,17\% (siswa mencapai nilai $\geq 70$ ). Dan dari hasil observasi terhadap pembelajaran dengan pengembangan dan penerapan LKS melalui diskusi terdapat peningkatan aktivitas yang signifikan yaitu dari skor rata-rata 18 menjadi 21 dimana skor ini masuk kategori aktif. Sedangkan berdasarkan hasil angket yang dibagikan kepada siswa terlihat proses pembelajaran mendapat respon yang baik dari siswa. Hal ini membuktikan bahwa pembelajaran dengan menggunakan pengembangan dan penerapan LKS memberikan dampak yang positif bagi siswa dalam proses belajar mengajar.
\end{abstract}

Kata Kunci: LKS, Hasil Belajar Siswa, Aktivitas Siswa

\begin{abstract}
Abstrak: The purpose of this study is to know whether the student's worksheet development and its application are able to increase the students' competence of the stoichiometry at the X grade of SMAN 1 Batulayar. The method of study used is class action research in which consists of two cycles and each of them has four steps such as planning, action, observation and reflection. This study focuses on basic laws of chemistry, the mole concept which includes the conversion of the number of moles to the number of particles, the amount of mass and volume number. Data was collected by test, observation and questionnaire. The result of study indicated that there were sifnificant increase of the students' competence and activities. On the second cycles was found that the students' post test result average was 77 and $78.57 \%$ student accomplish the topic. In contrast, on the first cycle the students average was 58 and only $54.17 \%$ student accomplish the topic. The students respond to the development and application of the students worksheet throughout discussion significantly improved whereas there are improvement in which previously only 18 students active during the leraning process, it increased into 21 students. It can be concluded that the development and application of the students' worksheet gives positive impact to the students' competence of the stoichiometry topic.
\end{abstract}

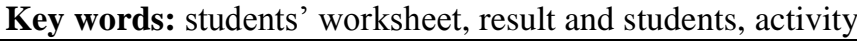

\section{PENDAHULUAN}

Berhasilnya pembangunan di bidang pendidikan ditentukan oleh banyak faktor diantaranya adalah mutu pendidikan. Mutu pendidikan dapat dilihat dari prestasi yang diraih oleh siswa. Hasil belajar merupakan indicator yang dipercaya bagi mutu pendidikan dan salah satu cirri sukses dalam belajar adalah memperoleh hasil belajar yang tinggi [1].

Pada kurikulum tingkat satuan pendidikan (KTSP) tahun 2006, mengharapkan pembelajaran di sekolah harus berorientasi pada penguasaan kompetensi yang telah ditentukan secara terintegratif. Untuk mencapai kompetensi- kompetensi tersebut, guru harus melaksanakan proses pembelajaran dengan memanfaatkan semua potensi yang ada mulai dari penggunaan alat peraga, pemilihan metode, strategi model pembelajaran, sumber belajar dan penggunaan media secara maksimal. Untuk mengetahui sejauh mana kompetensi-kompetensi itu telah dikuasai siswa, guru harus mengadakan evalusi terhadap proses dan hasil pembelajaran yang telah dilakukan secara periodik dan berkesinambungan. Indikator yang digunakan untuk menentukan siswa yang telah mencapai kompetensi tertentu adalah dengan cara membandingkan hasil belajar siswa dengan standar ketuntasan belajar minimal (SKBM) yang telah ditentukan sekolah. Jika hasil 
belajar siswa sama atau lebih dari SKBM yang ditentukan maka siswa tersebut dinyatakan telah tuntas [2-6].

Berdasarkan hasil observasi dan diskusi dengan guru kimia SMAN 1 Batulayar di peroleh bahwa hasil belajar kimia siswa kelas $\mathrm{X}$ terutama pada materi pokok stoikiometri pada tahun-tahun sebelumnya selama ini sangat rendah (rata-rata di bawah KKM). Rendahnya hasil belajar siswa dapat dilihat dari hasil ulangan siswa kelas $\mathrm{X}$ tahun pelajaran 2012/2013. Hal yang serupa juga dapat dilihat dari hasil ulangan harian kelas $\mathrm{X}$ tahun pelajaran 2014/2015.

Rendahnya hasil belajar siswa tersebut dipengaruhi oleh oleh beberapa faktor [5] diantaranya 1) siswa cenderung pasif dalam kegiatan belajar mengajar, 2) kemampuan dasar matematika masih rendah, kebanyakan siswa hanya menerima, mencatat dan melaksanakan aktivitas pembelajaran sesuai dengan yang diperintah guru, 3) siswa kurang perhatian yang disebabkan siswa tidak tertarik lagi dengan metode dan media pembelajaran yang kurang menarik, 4) siswa mengalami kesulitan dalam memahami konsep-konsep materi yang diajarkan, 5) motivasi, tingkat intelegensi dan gaya belajar siswa juga ikut mempengaruhi hasil belajar siswa, 6) minat baca yang sangat rendah, 7) kemampuan dasar matematika siswa juga di duga merupakan penyebab utama dari rendahnya hasil belajar siswa pada pokok bahasan stoikiometri. Dalam proses belajar mengajar permasalahan tidak hanya berasal dari siswa saja tetapi juga dari guru. Permasalahan dari guru diantaranya 1) dalam penyajian materi pelajaran kimia metode pembelajaran cenderung monoton, 2) media pembelajaran yang digunakan selama proses pembelajaran kurang menarik.

Sifat materi stiokiometri adalah hitungan, Selama ini pembahasan pokok bahasan stiokiometri dilakukan dengan pemberian rumusrumus dan contoh penyelesaian soal tanpa melibatkan siswa untuk ikut serta dalam membangun pemahaman, akibatnya siswa tidak terlatih untuk bekerja kelompok dalam menyelesaikan permasalahan dalam materi stiokiometri. Kondisi siswa yang seperti ini dapat diperbaiki dengan penggunaan metode pembelajaran kooperatif yang menggunakan kerja kelompok dalam kegiatan pembangunan konsepnya dan kurang tepat digunakan metode ceramah saja [7-13].

Penggunaan media dalam pembelajaran sangatlah dianjurkan. Untuk membuat media pembelajaran yang tepat diperlukan kreatifitas dan kemampuan guru dalam memilih materi pelajaran yang sesuai dengan media yang akan digunakan terhadap tingkat perkembangan siswa dan ketersediaan bahan, biaya serta waktu.
Jenis media pembelajaran bermacammacam, yaitu media berupa gambar, media berupa gerak, media berupa tulisan, dan media berupa suara. Media yang banyak dikenal orang adalah media audio, visual, dan audiovisual. Banyaknya jenis media yang ada dalam pembelajaran saat ini tentu menjadi tugas guru untuk memilih media yang tepat untuk anak didiknya yang sesuai dengan tujuan dan materi pembelajaran [7]. Salah satu media yang dapat digunakan untuk menunjang kegiatan pembelajaran adalah media LKS yang di buat sedemikian rupa oleh guru sehingga siswa lebih tertarik untuk belajar. Berdasarkan latar belakang di atas, peneliti telah melakukan penelitian dengan judul "Pengembangan LKS dan Penerapannya Untuk Meningkatkan Hasil Belajar Kimia Materi Pokok Stoikiometri Siswa kelas X di SMA Negeri 1 Batulayar Tahun pelajaran 2015/2016". Permasalahan yang dihadapi pada pada penelitian ini dapat dirumuskan sebagai berikut: Apakah hasil pengembangan LKS dapat diterapkan untuk meningkatkan hasil belajar siswa SMA Negeri 1 Batulayar tahun pelajaran 2015/2016?.

\section{METODE PENELITIAN}

Jenis penelitian ini merupakan penelitian tindakan kelas (PTK). Penelitian ini dimaksudkan untuk meningkatkan motivasi belajar siswa dan hasil belajar siswa yang berkaitan dengan proses pembelajaran di kelas, khususnya pada pemahaman konsep hukum-hukum dasar kimia dan konsep mol dengan menggunakan pengembangan dan penerapan LKS melalui metode diskusi kooperatif.

Penelitian tindakan kelas ini dilaksanakan pada semester ganjil tahun pelajaran 2015/2016 di SMA Negeri 1 Batulayar dengan jumlah siswa 29 orang terdiri dari 16 laki-laki dan 13 orang perempuan mulai dari bulan Oktober sampai Desember. Tindakan penelitian dilakukan sebanyak 2 kali pertemuan yang dibagi menjadi 2 siklus dimana setiap siklus dilaksanakan sebanyak 1 kali pertemuan. Jumlah jam pelajaran kimia dalam satu minggu adalah 3 jam pelajaran di mana 1 jam pelajaran waktunya 45 menit. Desain penelitian tindakan kelas ini adalah desain yang dikembangkan oleh Kemmis dan Mc. Taggart. Model ini terdiri dari empat komponen yaitu rencana, tindakan, observasi dan refleksi [3].

\section{HASIL PENELITIAN DAN PEMBAHASAN}

\section{Siklus I}

\section{a. Aktivitas Belajar}

Siklus I berlangsung selama $3 \times 45$ menit atau 1 kali pertemuan selama 3 jam pelajaran. Materi yang diajarkan dalam proses pembelajaran ini adalah hukum-hukum dasar kimia. Materi disajikan dalam bentuk pengembangan LKS yang 
dilengkapi dengan data-data yang harus di analisis oleh siswa untuk membuktikan hukum-hukum dasar kimia yang dikemukakan oleh beberapa ahli. Dari hasil observasi selama siklus I didapatkan data aktivitas siswa pada pembelajaran sudah baik

Berdasarkan data pada Tabel 3 terlihat aktivitas siswa sudah aktif hal itu bisa terlihat dari skor yang diperoleh dari masing-masing indikator aktivitas siswa. Selain itu, berdasarkan catatan para observer diperoleh 4 kelompok siswa (80\%) yang bekerjasama, 5 kelompok siswa yang bertanya (100\%), 2 kelompok siswa yang menanggapi pertanyaan (40\%), 1 kelompok siswa (20\%) yang menyimpulkan materi tersebut. Dan yang menjawab uji kompetensi di atas KKM sebanyak 2 kelompok siswa (40\%). Prosentase aktivitas belajar secara keseluruhan sebesar > $75 \%$. Data tersebut diperoleh melalui lembar observasi kegiatan siswa.

Dalam kegiatan diskusi kelompok ketepatan mengumpulkan tugas sebanyak 3 kelompok siswa atau $60 \%$. Berdasarkan data tersebut, ternyata pada siklus I menunjukkan bahwa siswa masih kurang aktif dan kurang memberikan respon positif dalam setiap pembelajaran yang dikembangkan dalam penelitian ini. Dilihat dari ketetapatan hal tersebut terlihat dari kesiapan siswa mengikuti pembelajaran, antusiasme siswa dalam mengikuti pembelajaran, interaksi siswa dengan guru, kerja sama kelompok dan partisipasi siswa dalam menyimpulkan hasil belajar.

mengumpulkan tugas diberikan oleh guru menunjukkan bahwa minat, motivasi belajar dan keinginan untuk belajar siswa masih rendah.

\section{b. Hasil Belajar Siswa}

Setelah proses pembelajaran pada siklus I selesai, selanjutnya pada akhir siklus dilakukan tes (Pos test) untuk mengetahui kemampuan siswa dalam menyerap materi yang telah dibahas. Dari hasil pos test pada siklus I diperoleh nilai rata-rata siswa sebesar 58 dan jumlah siswa yang memenuhi kriteria ketuntasan belajar yang ditetapkan sekolah (nilai > 70,00) sebanyak 13 orang atau $54,17 \%$. Bila dilihat dari ketuntasan belajar secara klasikal, hasil tindakan pada siklus I belum menunjukkan keberhasilan yang memuaskan karena ketuntasan klasikal masih di bawah $75 \%$. Nilai hasil belajar yang dicapai pada siklus I ini belum memenuhi indikator keberhasilan tindakan yang diinginkan $(75 \%$ siswa memperoleh nilai > 70,00) (Tabel 4).

Tabel 3. Skor Rata-Rata Aktivitas Siswa dan Guru pada Kegiatan Siklus I

\begin{tabular}{ccccc}
\hline Siklus & \multicolumn{2}{c}{ Kegiatan Guru } & \multicolumn{2}{c}{ Aktivitas Belajar Siswa } \\
\hline \multirow{2}{*}{1} & Skor & Kriteria & Skor & Kriteria \\
\cline { 2 - 5 } & 20 & aktif & 18,37 & aktif \\
\hline
\end{tabular}

Tabel 4. Prosentase Siswa yang Mencapai Ketuntasan Belajar (Nilai Post test) pada Siklus I

\begin{tabular}{ccc}
\hline \multirow{2}{*}{ Nilai } & \multicolumn{2}{c}{ SIKLUS I } \\
\cline { 2 - 3 } & Jumlah (orang) & $\%$ \\
\hline$<60,00$ & 7 & 29 \\
$60-70$ & 4 & 16 \\
$\geq 70$ & 13 & 54,17 \\
\hline Rata-rata & \multicolumn{3}{c}{58} \\
\hline
\end{tabular}

Tabel 5. Data kegiatan guru dan aktivitas belajar siswa selama pembelajaran siklus II

\begin{tabular}{ccccc}
\hline Siklus & \multicolumn{2}{c}{ Kegiatan Guru } & \multicolumn{2}{c}{ Aktivitas Belajar Siswa } \\
\hline \multirow{2}{*}{ II } & Skor & Kriteria & Skor & Kriteria \\
\cline { 2 - 5 } & 23 & aktif & 21 & aktif \\
\hline
\end{tabular}

Tabel 6. Prosentase Siswa yang Mencapai Ketuntasan Belajar (Nilai Post test)

\begin{tabular}{ccc}
\hline \multirow{2}{*}{ Nilai } & \multicolumn{2}{c}{ SIKLUS II } \\
\cline { 2 - 3 } & Jumlah (orang) & $\%$ \\
\hline$<60,00$ & 0 & 0 \\
$60-69$ & 6 & 21 \\
$\geq 70$ & 22 & 78,57 \\
\hline Rata-rata & \multicolumn{2}{c}{77} \\
\hline
\end{tabular}




\section{c. Refleksi}

Berdasarkan hasil observasi terhadap guru dan refleksi pada siklus I, keadaan ini disebabkan oleh:

1. Materi yang terlalu padat yang tidak sesuai dengan alokasi waktu yang ada

2. Jumlah LKS yang di bagikan ke siswa kurang sehingga ada beberapa siswa yang tidak berkonsentrasi membaca dan menyelesaikan kegiatan diskusi karena mengandalkan ketua kelompok

3. Jarak duduk siswa dalam satu kelompok cukup jauh sehingga interaksi antar kelompok tidak maksimal

4. Cuaca yang begitu panas dimana sebagian besar siswa sulit berkonsentrasi di akhir pembelajaran karena kondisi fisik yang lebih mudah lelah dan keringat yang mengganggu sehingga pada saat kegiatan pos test sebagian besar siswa sulit berkonsentrasi.

5. Guru kurang memberikan waktu tunggu yang cukup kepada siswa untuk menjawab pertanyaan.

6. Guru tidak memberikan penjelasan yang cukup tentang langkah-langkah pembuktian setiap hukum dan masih mengandalkan LKS yang sudah dikembangkan sehingga bagi siswa yang memiliki kemampuan rendah mengalami kesulitan dalam memahami konsep-konsep kimia

7. Kurangnya peran ketua kelompok dalam membimbing anggota kelompoknya.

Dari data pada Tabel 5 aktivitas siswa mengalami peningkatan yang signifikan hal ini sangat mempengaruhi hasil belajar siswa. Selain itu, berdasarkan catatan para observer diperoleh 4 kelompok siswa $(80 \%)$ yang bekerjasama, 5 kelompok siswa yang bertanya (100\%), 2 kelompok siswa yang menanggapi pertanyaan (40\%), 3 kelompok siswa (60\%) yang menyimpulkan materi tersebut. Dan yang menjawab uji kompetensi di atas KKM sebanyak 4 kelompok siswa (80\%). Prosentase aktivitas belajar secara keseluruhan sebesar $>75 \%$. Data tersebut diperoleh melalui lembar observasi kegiatan siswa dan catatan guru dan observer yang tidak nampak dalam lembar observasi.

Dalam kegiatan diskusi kelompok ketepatan mengumpulkan tugas sebanyak 4 kelompok siswa atau $80 \%$. Berdasarkan data tersebut, ternyata pada siklus II menunjukkan bahwa siswa cukup aktif dan selalu memberikan respon yang positif dalam setiap pembelajaran yang dikembangkan dalam
Dengan mengevaluasi aktivitas dan hasil belajar yang diperoleh pada siklus I maka

perlu adanya perbaikan dalam melaksanakan siklus II antara lain dengan lebih memotivasi dan menarik perhatian siswa pada materi yang sedang dibahas, terutama aspek-aspek yang masih belum optimal dilaksanakan, yaitu tujuh butir kelemahan tersebut di atas, terutama peran guru yang perlu diperbaiki dan jumlah LKS yang dibagikan untuk siswa.

\section{Siklus II}

\section{a. Aktivitas Belajar}

Siklus II berlangsung selama 3 x 45 menit atau 1 kali pertemuan selama 3 jam pelajaran. Materi yang diajarkan dalam proses pembelajaran ini adalah konsep mol. Materi disajikan dalam bentuk pengembangan LKS yang dilengkapi dengan contoh-contoh soal dan latihan soal yang harus di selesaikan oleh siswa untuk mengkonversikan jumlah mol dengan jumlah partikel, massa zat dan volume zat.

Dari hasil observasi selama siklus II didapatkan data aktivitas siswa pada pembelajaran sudah baik hal tersebut terlihat dari kesiapan siswa mengikuti pembelajaran, antusiasme siswa dalam mengikuti pembelajaran, interaksi siswa dengan guru, kerja sama kelompok dan partisipasi siswa dalam menyimpulkan hasil belajar.

penelitian ini. Dilihat dari ketetapatan mengumpulkan tugas diberikan oleh guru menunjukkan bahwa minat, motivasi belajar dan keinginan untuk belajar siswa cukup tinggi.

\section{b. Hasil Belajar Siswa}

Setelah proses pembelajaran pada siklus II selesai, selanjutnya pada akhir siklus dilakukan tes (Postest) untuk mengetahui kemampuan siswa dalam menyerap materi yang telah dibahas. Dari hasil postest pada siklus I diperoleh nilai rata-rata siswa sebesar 77 dan jumlah siswa yang memenuhi kriteria ketuntasan belajar yang ditetapkan sekolah (nilai > 70,00) sebanyak 22 orang atau 78,57\%. Bila dilihat dari ketuntasan belajar secara klasikal, hasil tindakan pada siklus II sudah menunjukkan keberhasilan yang memuaskan karena sudah mencapai $75 \%$. Nilai hasil belajar yang dicapai pada siklus II ini sudah memenuhi indikator keberhasilan tindakan yang diinginkan $(75 \%$ siswa memperoleh nilai $>70,00)$ (Tabel 6). 


\section{c. Motivasi}

Setelah proses pembelajaran ditempuh sebanyak 2 kali pertemuan mulai dari siklus I sampai siklus II, siswa diberikan angket isian untuk mengetahui motivasi siswa dengan pengembangan LKS model pembelajaran kooperatif (diskusi) karena dengan adanya motivasi belajar tersebut akan ada dorongan belajar dalam diri siswa. Angket yang diberikan siswa ditanyakan beberapa pertanyaan diantaranya Saya senang dengan kegiatan belajar kimia menggunakan LKS berwarna dan bergambar yang dibuat oleh guru, Saya merasa mudah memahami materi pelajaran dengan menyelesaikan tugas-tugas dalam LKS, Saya senang belajar kimia dengan cara berkelompok, Saya merasa mudah memahami materi pelajaran melalui diskusi kelompok, menurut saya kegiatan belajar dengan model kooperatif menyenangkan, Achievement (penghargaan) yang diberikan guru di akhir pembelajaran menambah motivasi saya dalam belajar kimia, Menurut saya kegiatan belajar seperti ini perlu dikembangkan

Berdasarkan hasil angket yang diberikan kepada siswa, diperoleh hasil bahwa siswa yang setuju dengan kegiatan belajar kimia menggunakan LKS berwarna dan bergambar yang dibuat oleh guru sebanyak 21 orang siswa $(75 \%)$, ragu-ragu 5 orang $(17,86 \%)$ dan tidak setuju sebanyak 2 orang $(7,14 \%)$, siswa yang merasa mudah memahami materi pelajaran dengan menyelesaikan tugas-tugas dalam LKS, 14 orang siswa setuju (50\%), raguragu 10 orang siswa $(35,71 \%)$ dan tidak setuju sebanyak 4 orang $(14,29)$, siswa yang senang belajar kimia dengan cara berkelompok, 19 orang siswa setuju $(67,86 \%)$, ragu-ragu 3 orang $(10,71 \%)$ dan tidak setuju sebanyak 6 orang $(21,43 \%)$, siswa yang mudah memahami materi pelajaran melalui diskusi kelompok, 17 orang siswa setuju $(60,71 \%)$, ragu-ragu sebanyak 5 orang siswa $(17,86)$, tidak setuju sebanyak 6 orang siswa $(21,43 \%)$, siswa yang senang dengan kegiatan belajar dengan model kooperatif , 16 orang siswa setuju $(57,14 \%), 10$ orang siswa ragu-ragu $(35,71)$, sebanyak 2 orang siswa tidak setuju $(7,14 \%)$, Achievement (penghargaan) yang diberikan guru di akhir pembelajaran menambah motivasi saya dalam belajar kimia, 17 orang siswa setuju $(60,71 \%), 9$ orang siswa ragu-ragu $(32,14)$, sebanyak 2 orang siswa tidak setuju (7,14\%), siswa yang menginginkan kegiatan belajar seperti ini perlu dikembangkan, 22 orang siswa setuju $(78,57 \%)$, sebanyak 4 orang siswa ragu-ragu $(14,29 \%)$ dan sebanyak 2 orang siswa tidak setuju $(7,14 \%)$.

\section{d. Refleksi}

Siklus II berlangsung selama 3 x 45 menit atau satu kali pertemuan sebanyak 3 jam pelajaran. Materi yang diajarkan dalam proses pembelajaran ini adalah sub materi pokok konsep mol. Proses pembelajaran berlangsung sebagaimana siklus I dengan perbaikan beberapa teknik pembelajaran sesuai hasil refleksi pada siklus I.

aktivitas siswa mengalami kenaikan untuk setiap komponen. Kenaikan ini menunjukkan bahwa siswa semakin tertarik dan keingintahuan siswa terhadap materi yang dibahas cukup tinggi. Jika dibandingkan dengan aktivitas siswa pada siklus I, maka pada siklus II terjadi peningkatan aktivitas siswa yang positif . Adanya peningkatan aktivitas ini menunjukan adanya perubahan motivasi dan minat siswa terhadap mata pelajaran kimia setelah mengikuti proses pembelajaran dengan diskusi kelompok . Jika dibandingkan dengan nilai rata-rata hasil belajar yang dicapai siswa pada siklus I, pada siklus II mengalami peningkatan prosentase sebesar $24,4 \%$ dan kenaikan rata-rata sebesar 19.

Dengan hasil yang diperoleh pada siklus II berarti indikator keberhasilan tindakan sudah tercapai, bila ditinjau dari segi peningkatan hasil belajar dan aktivitas siswa dari siklus ke siklus. Hal ini antara lain disebabkan siswa telah terbiasa dengan metode pembelajaran yang sudah dilaksanakan, sehingga dapat mempermudah dalam memahami konsep-konsep kimia dan guru dalam proses pembelajaran hanya bertindak sebagai fasilitator.

Berdasarkan hasil observasi dan refleksi yang dilakukan oleh guru beserta observer menyatakan bahwa pembelajaran pada siklus II masih memiliki beberapa kelemahan, antara lain:

1. Guru masih belum memberikan waktu tunggu yang cukup kepada siswa untuk menjawab pertanyaan dan menyampaikan pendapatnya, disebabkan waktu yang terbatas.

2. Guru masih belum memberikan motivasi pada siswa yang cukup, terutama dalam memberikan penguatan.

3. Bimbingan guru pada siswa untuk membuat kesimpulan sendiri melalui kelompok belum maksimal, disebabkan keterbatasan waktu dan banyaknya siswa yang membutuhkan bimbingan secara individu.

Oleh sebab itu, dalam pengembangan pembelajaran selanjutnya untuk menerapkan metode dan teknik pembelajaran sebagaimana penelitian ini, guru perlu memperbaiki beberapa kelemahan tersebut. Di samping itu, ada beberapa yang perlu diperbaiki dalam pembelajaran yang lain, yaitu:

1. Hendaknya guru dapat merinci soal-soal yang tidak dapat dikerjakan siswa

2. Diskusi yang diselenggarakan hendaknya disesuaikan dengan waktu jam pelajaran, sehingga tidak melewati jam pelajaran.

Berdasarkan uraian di atas, bahwa proses pembelajaran hukum-hukum dasar kimia dan konsep mol dengan metode kooperatif (diskusi) terdapat hubunga antara minat belajar siswa selama 
proses pembelajaran berlangsung dengan hasil belajar setelah proses pembelajaran dilaksanakan. Jadi bisa dikatakan apabila siswa aktif pada saat diskusi membahas materi dan soal-soal pembelajaran baik dalam hal bertanya atau mengemukakan pendapat maka berarti siswa sudah mengerti dan paham apa yang sedang dipelajarinya, sehingga hasil belajarnya pun cukup memuaskan. Dengan demikian, apabila pemahaman konsep sudah baik/meningkat maka bisa dipastikan hasil belajarnya pun baik/meningkat.

\section{KESIMPULAN}

Berdasarkan hasil penelitian maka diperoleh kesimpulan sebagai berikut:

1. Pengembangan LKS dapat diterapkan untuk meningkatkan hasil belajar siswa di SMA Negeri 1 Batulayar Tahun pelajaran 2015/2016

2. Penggunaan LKS telah dapat meningkatkan hasil belajar siswa dari siklus I ke siklus II sebesar $24,4 \%$ (dari $54,17 \%$ menjadi $78,57 \%$ )

3. Penggunaan LKS telah dapat meningkatkan aktivitas belajar siswa dari siklus I ke siklus II sebesar 3 (dari 18 menjadi 21)

4. Penggunaan LKS telah dapat meningkatkan minat dan motivasi belajar siswa.

\section{DAFTAR PUSTAKA}

[1] Nasution, 2001. Berbagai Pendekatan Dalam Proses Belajar-Mengajar. Bina Aksara. Jakarta.

[2] Asra, Sumiati. 2007. Metode Pembelajaran. Bandung : CV. Wacana Prima

[3] Depdiknas, 2004, Pedoman Penelitian Tindakan Kelas, Jakarta, Puskur, Balitbang Depdiknas

[4] Slameto, 2003. Belajar dan faktor-faktor yang mempengaruhinya. Rineka Cipta. Jakarta

[5] Sudjana, Nana. (1990). Cara Belajar Siswa Aktif dalam Proses Belajar Mengajar, Bandung. Sinar Baru.

[6] Sudjana, Nana. (1990). Penilaian Hasil Proses Belajar Mengajar. Bandung: PT. Remaja Rosdakarya.

[7] Arsyad, Azhar. 2008. Media Pembelajaran. Jakarta: PT Raja Grafindo Persada.

[8] Azizah, N. 2016. Pengembangan LKS dan penerapannya dalam pembelajaran kooperatif tipe STAD untuk meningkatkan aktivitas dan hasil belajar kimia siswa kelas XI IPA SMAN 1 Batulayar tahun pelajaran 2015/2016. Jurnal Pijar Mipa, 11(1).

[9] Wijayanti, A. 2016. Implementasi model pembelajaran kooperatif tipe tgt sebagai upaya meningkatkan pemahaman konsep fisika dasar mahasiswa pendidikan IPA. Jurnal Pijar Mipa, 11(1).

[10] Raksun, A. 2009. Implementasi pembelajaran kooperatif untuk meningkatkan motivasi dan hasil belajar mahasiswa program studi pendidikan fisika fkip universitas mataram pada matakuliah biologi dasar. Jurnal pijar MIPA, 4(1).

[11] Aryana, I. G. M. R., Al Idrus, A., \& Harjono, A. 2015. Pengaruh model pembelajaran kooperatif nht dan stad terhadap hasil belajar sikap siswa sma negeri 2 gerung. Jurnal pijar $M I P A, 10(2)$.

[12] Yulianti, R., Muntari, M., \& Haris, M. 2015. Pengaruh model pembelajaran kooperatif tipe two stay two stray (tsts) dengan pendekatan brain-based learning terhadap hasil belajar kimia materi pokok struktur atom dan sistem periodik unsur pada siswa kelas X SMAN 1 Kediri. Jurnal pijar MIPA, 10(1).

[13] Irzi, R. H., Sripatmi, S., \& Hapipi, H. 2015. Penerapan model pembelajaran kooperatif tipe snowball throwing pada pembelajaran segiempat untuk meningkatkan aktivitas dan prestasi belajar siswa SMPN 1 lingsar kelas VII-1 tahun pelajaran 2012/2013. Jurnal Pijar MIPA, 10(1). 